\title{
Pre-Phase I Aging Assessment of the BWR Isolation Condenser System
}

R. D. Orton

August 1995

Prepared for

Division of Enginering

Office of Nuclear Regulatory Research

U.S. Nuclear Regulatory Commission under Contract DE-AC06-76RLO 1830

Pacific Northwest Laboratory Operated for the U.S. Department of Energy by Battelle Memorial Institute 


\title{
DISCLAIMER
}

This report was prepared as an account of work sponsored by an agency of the United States Government. Neither the United States Government nor any agency thereof, nor Battelle Memorial Institute, nor any of their employees, makes any warranty, express or implied, or assumes any legal liability or responsibility for the accuracy, completeness, or userilness of any information, apparatus, product, or process disclosed, or represents that its use would not infringe privately owned rights. Reierence herein to any specific commercial product, process, or service by trade name, traciemark, manufacturer, or otherwise does not necessarily constitute or imply its endorsement, recommendation, or favoring by the United States Government or any agency thereoi, or Battelle Memorial Institute. The views and opinions of authors expressed herein do not necessarily state or reflect those of the United States Government or any agency thereoi.

\author{
PACIFIC NORTHWEST LABORATORY \\ operated by \\ BATTELLE MEMORIAL INSTITUTE \\ for the \\ UNITED STATES DEPARTMENT OF ENERGY \\ under Contract DE-AC06-76RLO 1830
}

Printed in the United States of America

Available to DOE and DOE contractors from the

Office of Scientinic and Technical Information, P.O. Box 62, Oak Ridge, TN 37831; prices available from (615) 576-8401. FTS 626-8401.

Available to the public from the National Technical Information Service,

U.S. Department oi Commerce, 5285 Port Royal Rd., Springiield, VA 22161 
PNL-10719

UC-506

\section{Pre-Phase I Aging Assessment of the BWR Isolation Condenser System}

R. D. Orton

August 1995

Prepared for Division of Engineering Office of Nuclear Regulatory Research U.S. Nuclear Regulatory Commission under Contract DE-AC06-76RLO 1830

Pacific Northwest Laboratory Richland, Washington 99352 
.

. 


\section{Summary}

The isolation condenser system (ICS) is part of the emergency core cooling system in five U.S. boiling-water reactors. In the event that the reactor pressure vessel becomes isolated from the main condenser, the ICS removes decay heat from the reactor. The ICS is important to reactor safety because it is relied on to help mitigate core damage during a loss-of-coolant accident.

In support of the U.S. Nuclear Regulatory Commission's Nuclear Plant Aging Research (NPAR) Program, staff from the Pacific Northwest Laboratory researched the aging of the ICS by reviewing available industry databases. Each component of the ICS was evaluated to 1) identify applicable aging issues and also to 2 ) determine if the component had already been studied as a part of other NPAR assessments.

The results of this preliminary study indicate that most of the critical ICS components have been previously evaluated by the NPAR program. The one ICS component that has not been specifically studied is the isolation condenser itself. There is little evidence in the databases to suggest that there have been problems with the isolation condenser. Only one plant, Millstone Unit 1, has ever had an isolation condenser tube failure problem recorded. This instance resulted from events that occurred early in the life of the plant. The problem was remedied through tube replacement.

The isolation condenser and the pressurized-water reactor (PWR) steam generator were compared to illustrate that even though the isolation condenser is a heat exchanger, it is not subjected to the same service dynamics as the PWR steam generator. The isolation condenser operates for most of its service life in a relatively benign, static environment, resulting in a comparatively good service record.

PNL staff recommend that the results of this research be used to continue studying the ICS to determine if the aging isolation condenser tubes are being adequately maintained. This new study should include an evaluation of the current inspection methods and a verification that they are effective in identifying tube aging degradation, such as intergranular stress corrosion cracking. Continued study may also provide beneficial input into the design of the Simplified Boiling Water Reactor. 


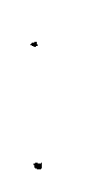




\section{Acronyms}

$\mathrm{AC}$

ADS

BWR

DC

ICS

IPE

LER

LOCA

NPAR

NPE

NPRDS

NRC

ORNL

PNL

PWR

SBWR

SRV alternating current

automatic depressurized system

boiling-water reactor

direct current

isolation condenser system

individual plant evaluation

license event report

loss-of-coolant accident

nuclear plant aging research

nuclear power experience

nuclear plant reliability database system

U.S. Nuclear Regulatory Commission

Oak Ridge National Laboratory

Pacific Northwest Laboratory

pressurized-water reactor

simplified boiling water reactor

safety relief valve 


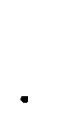




\section{Contents}

Summary $\quad \ldots \ldots \ldots \ldots \ldots \ldots \ldots \ldots \ldots \ldots \ldots \ldots \ldots \ldots$ iii

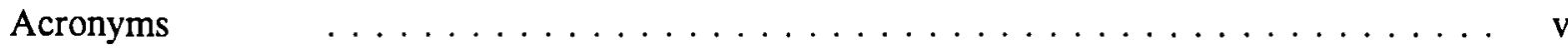

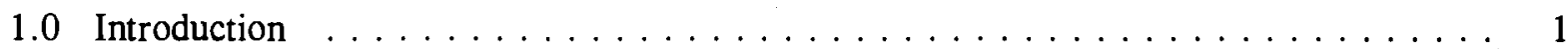

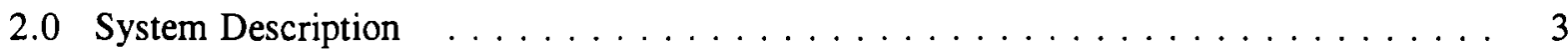

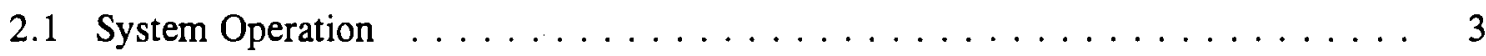

2.2 Critical Component Description $\ldots \ldots \ldots \ldots \ldots \ldots \ldots \ldots \ldots$

2.2 .1 Isolation Condenser $\ldots \ldots \ldots \ldots \ldots \ldots \ldots \ldots \ldots$

2.2.2 Steam Supply and Condensate Return Valves $\ldots \ldots \ldots \ldots \ldots$

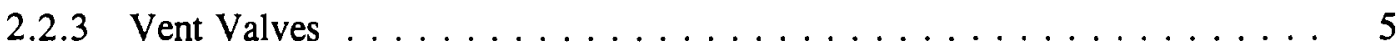

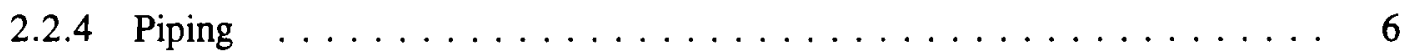

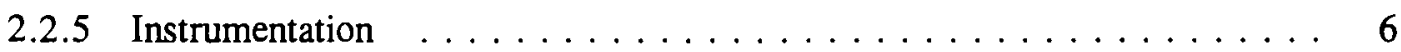

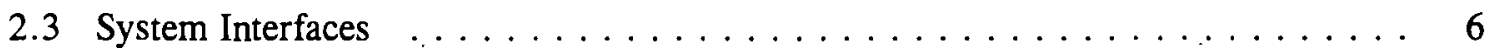

2.3.1 Shell Makeup Water Systems $\ldots \ldots \ldots \ldots \ldots \ldots \ldots$

2.3.2 Reactor Protection System $\ldots \ldots \ldots \ldots \ldots \ldots \ldots$

2.3.3 Reactor Recirculation System $\ldots \ldots \ldots \ldots \ldots$

2.3 .4 Main Steam System $\ldots \ldots \ldots \ldots \ldots \ldots \ldots$

2.3.5 Instrument/Service Air Systems $\ldots \ldots \ldots \ldots \ldots$

2.3.6 Electrical Systems $\ldots \ldots \ldots \ldots \ldots \ldots$

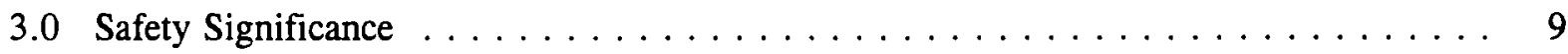

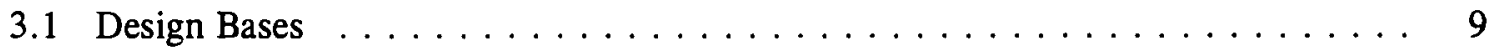

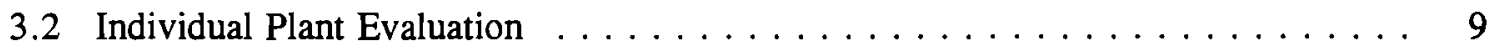

3.3 Regulatory Guidance $\ldots \ldots \ldots \ldots \ldots \ldots \ldots \ldots \ldots$ 


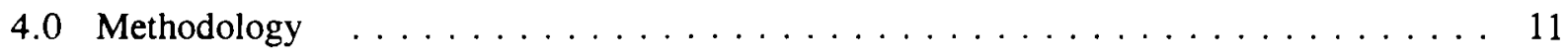

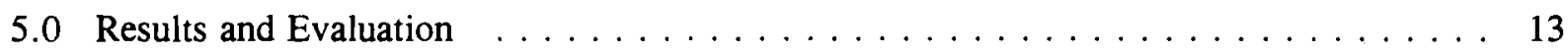

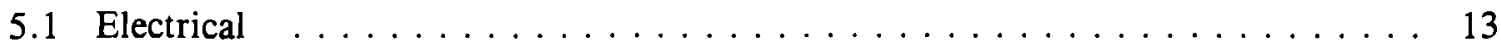

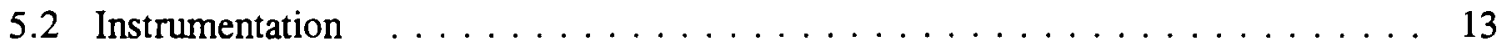

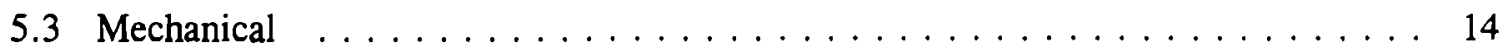

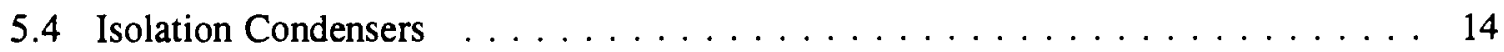

6.0 Simplified BWR Isolation Condenser System $\ldots \ldots \ldots \ldots \ldots$

7.0 Conclusions and Recommendations $\ldots \ldots \ldots \ldots \ldots \ldots$

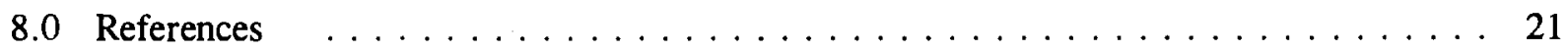

Appendix A - Bulletin 76-001 - DWR Isolation Condenser Tube Failure $\ldots \ldots \ldots$. . . . . A.1 


\subsection{Introduction}

In support of the U.S. Nuclear Regulatory Commission's Nuclear Plant Aging Research (NPAR) Program, staff from the Pacific Northwest Laboratory (PNL) performed a pre-phase I assessment to identify aging issues for the isolation condenser system (ICS) used in commercial boiling-water reactors (BWRs). The objective of the investigation was to evaluate the ICS and determine if further research is needed to detect and mitigate degradation due to aging mechanisms such as corrosion and mechanical wear.

The ICS is an emergency core cooling system designed to provide emergency cooling to the reactor when the reactor vessel becomes isolated from the turbine and main condenser by closure of the main steam isolation valves. In the event the main condenser is not available as a heat sink, the ICS removes residual and decay heat from the reactor and depressurizes the reactor vessel. Natural circulation provides the driving head for reactor coolant through the isolation condenser tubes. The shell side of the isolation condenser is filled with water that boils off to the atmosphere to remove heat transferred from the reactor. The shell side of the isolation condenser vents to the atmosphere.

Five BWRs in the United States have an ICS and fall within the scope of this report: Oyster Creek, Nine Mile Point 1, Millstone Unit 1, and Dresden 2 and 3. Big Rock Point, an early model BWR, has a component called an emergency condenser that performs a similar function to the ICS. However, because of its unique design, it was not included within the scope of this assessment.

Section 2.0 of this report describes the ICS components and system interfaces, and Section 3.0 reviews the safety significance of the ICS that addresses design bases, individual plant evaluations (IPEs), and regulatory guidance. Section 4.0 describes the methodology and results of the review. A comparison of the condensers used in the ICS and pressurized-water reactor (PWR) steam generators is provided in Section 5.0. Section 6.0 briefly describes the ICS planned for use with the Simplified Boiling Water Reactor (SBWR), and Section 7.0 provides the conclusions and recommendations of the investigation. 
.

. 


\subsection{System Description}

This section describes the general operation of the ICS at the five plants. There may be unique system variations from plant to plant, but the design bases for the ICS remain the same. Some of the more important plant differences are noted within the text of the system description.

\subsection{System Operation}

The flow path for a typical ICS loop is illustrated in Figure 1. During standby operation, with the reactor at power, the inboard and outboard (inside and outside of the drywell enclosure) steam supply isolation valves ( 1 and 2 ) and the inboard condensate return valve (4) are open. The outboard condensate return isolation valve (3) is closed. Steam line vent valves (5) are normally open to vent noncondensible gases from the isolation condenser steam supply headers to the main steam lines and to permit a small amount of steam flow through the system to keep the steam headers warm. The vent valves are interlocked to close anytime the outboard condensate return valve (3) is opened. The shell side of the isolation condenser is continuously vented to the atmosphere.

The ICS may be manually initiated, or automatically initiated on high reactor pressure or low reactor water level. Upon system initiation, the outboard condensate return valve (3) opens and the vent valves (5) close. Steam flows from the reactor vessel to the isolation condenser through the steam inlet isolation valves ( 1 and 2 ). Steam is condensed in the isolation condenser tube bundles, and the condensed steam is returned to the reactor through the condensate return isolation valves ( 3 and 4 ) via the reactor recirculation system. During system operation, the demineralized water in the shell side of the isolation condenser is boiled off and vented outside the reactor building to the atmosphere. The boiled-off water is replaced by the condensate transfer system or the fire water system. Radiation monitors will detect any radioactivity release from the shell side of the isolation condenser. High radiation levels will initiate an alarm in the control room. The alarm warns of a possible tube leak and the potential release of radioactive primary coolant to the environment.

The ICS is designed to automatically isolate itself from the reactor pressure vessel in the event of a system pipe break. This isolation will mitigate the loss of reactor coolant inventory. The pipe break is sensed by monitoring for high flow rates in the steam supply and the condensate return lines. Flow is sensed by measuring the differential pressure across piping elbows in each of the steam supply and condensate return lines. The inboard and outboard steam supply valves, the inboard and outboard condensate return valves, and the vent valves will close if the differential pressure exceeds three times the normal flow value for a short time delay (plant-dependent, approximately 3 to $15 \mathrm{~s}$ ). 


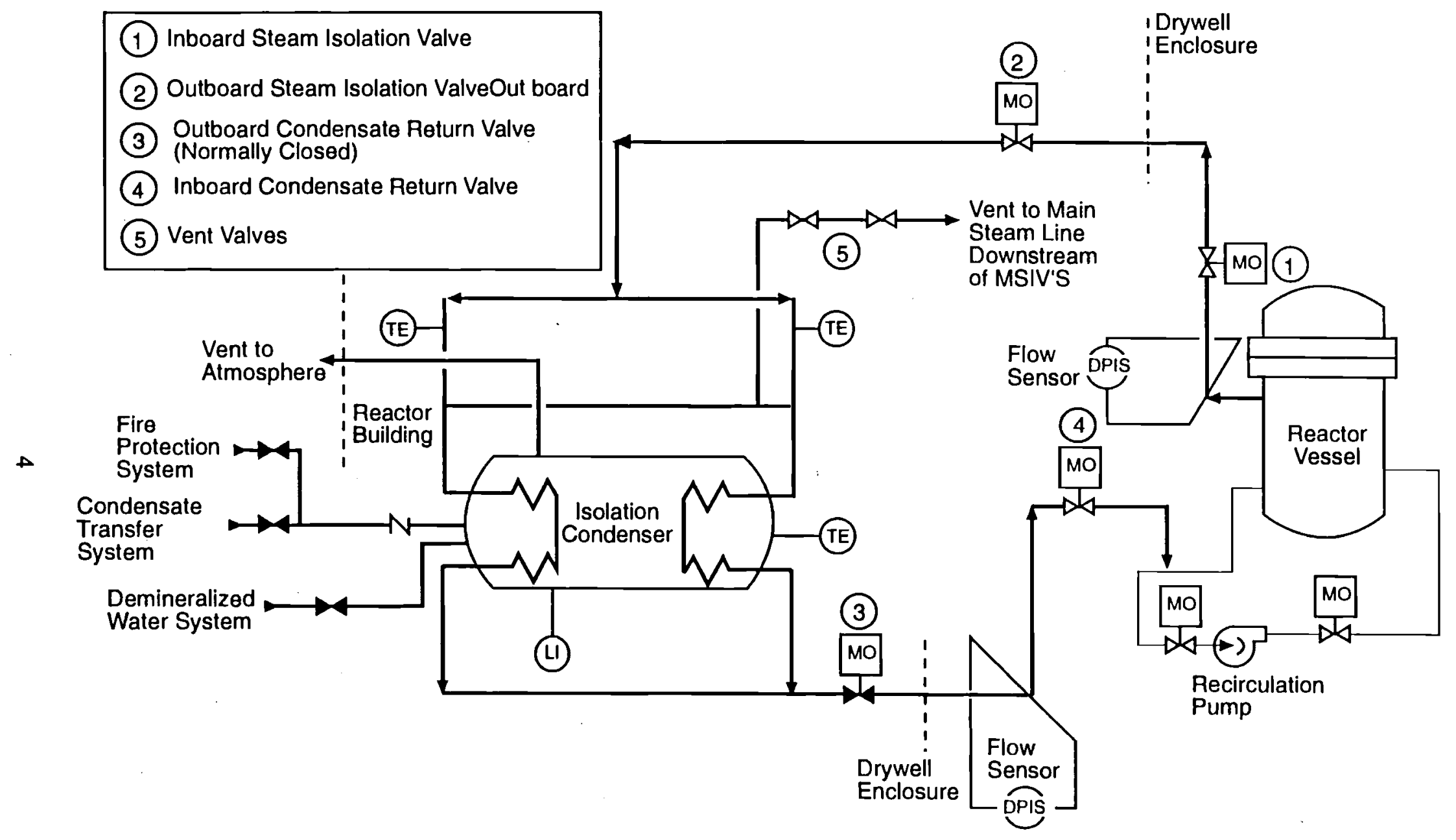

S9508021.1

Figure 1. Typical ICS Loop Flow Path 


\subsection{Critical Component Description}

Components that are critical to the initiation, isolation, and safe operation of the ICS were the focus of this aging study. These components consist of the isolation condenser, steam supply valves, condensate return valves, vent valves, system piping, and system instrumentation.

\subsubsection{Isolation Condenser}

Isolation condensers are horizontal, shell-and-tube heat exchangers with a capacity rating of about $3 \%$ reactor power. Each condenser has two sets of stainless steel U-tubes (Millstone Unit 1 has Inconel 600 tubes), one set on each end of the condenser. The tubes are designed to meet the design pressure and temperature conditions of the reactor. The shell of each isolation condenser is constructed out of carbon steel, and its maximum internal pressure is about $1.0 \times 10^{5} \mathrm{~Pa}(15 \mathrm{psig})$.

The major differences among the plants that fall within the scope of this report are the number of isolation condensers at each facility. Millstone Unit 1 and Dresden 2 and 3 each have one isolation condenser loop and one isolation condenser per loop. Oyster Creek has two isolation condenser loops with one isolation condenser per loop. Nine Mile Point 1 has two isolation condenser loops and two isolation condensers per loop. The major valves for each loop are the same, i.e., two steam supply and two condensate return isolation valves. The schematic presented as Figure 1 represents any given ICS loop. The exception would be Nine Mile Point 1 where the single isolation condenser would be replaced with two isolation condensers that operate in parallel. Each of the Nine Mile Point 1 isolation condensers has only one stainless steel tube bundle.

\subsubsection{Steam Supply and Condensate Return Valves}

The steam supply and condensate return valves are typically $25.4-$ to $35.6-\mathrm{cm}$ (10- to 14 -in.) motor-operated gate valves and are rated for reactor design pressures and temperatures. The inboard valves are AC-powered, and the outboard valves are DC-powered. The outboard valves are located in the reactor building and have the capability to be manually operated even during plant operation.

\subsubsection{Vent Valves}

The vent valves are small bore [1.9 to $2.5 \mathrm{~cm} \mathrm{(3/4} \mathrm{to} 1$ in.)], air-operated valves and are rated for reactor design pressures and temperatures. The operating air is supplied by the instrument/service air systems via DC-powered solenoid valves. The vent valves are opened by air pressure and closed by spring pressure. If the vent valves were to fail closed during ICS standby operation, noncondensible gases could build up in the isolation condenser and then be forced into the isolation tube bundle on system initiation. The presence of noncondensibles in the tube bundle inhibits condensation and natural circulation. 


\subsubsection{Piping}

Most piping in the ICS is stainless steel with pipe diameters ranging from 1.3 to $40.6 \mathrm{~cm}(1 / 2$ to 16 in.). The piping of critical concern is that which is subjected to reactor operating pressures and temperatures.

\subsubsection{Instrumentation}

Flow in the ICS steam and condensate lines is measured by differential pressure detectors located in the piping elbows of the steam supply and condensate return lines. The steam supply detector senses flow in the elbow upstream of the inboard isolation valve. The condensate return detector senses flow downstream of the outboard condensate return valve. High flow in any of the lines monitored by these detectors is an indication of a system pipe break, and isolation is required.

System initiation input (low reactor water level and/or high reactor pressure) is supplied by the reactor protection system.

Other instrumentation that is used for system monitoring but has no automatic initiation or isolation input includes the following:

- condenser shell side level indication: level must be maintained to ensure that the ICS will operate within technical specification parameters

- condenser shell temperature indication: high temperature indicates condenser tube leakage or condensate return valve leakage

- area temperature monitoring: high temperature in the area adjacent to the isolation condenser indicates possible system rupture

- steam line pressure indication: this is for information only; during standby operation this pressure should be the same as reactor pressures

- shell vent line radiation monitoring: increased radiation levels indicate possible tube leak and potential reactor coolant release.

\subsection{System Interfaces}

The ICS interfaces with a number of other reactor systems: 1) shell makeup water systems, 2) reactor protection systems, 3) reactor recirculation systems, 4) main steam systems,

5) instrument/service air systems, and 6) electrical systems. The following sections describe how each of these systems interface with the ICS. 


\subsubsection{Shell Makeup Water Systems}

The demineralized water system provides initial fill and makeup water to the shell side of the isolation condensers for day-to-day evaporation. For this type of operation, some plants have the capability to automatically supply makeup water to the isolation condenser. Depending on plant design, the demineralized water system may not be capable of acting as a makeup source during isolation condenser operation. Operation of the isolation condensers can continue for about 30 to 90 min before the volume of water stored on the shell side of the isolation condenser will be depleted. This interval allows sufficient time to initiate makeup water flow to the shell side of the condenser via the condensate transfer system or the fire water system.

Some drawbacks were identified when using the condensate transfer system or the fire water system for makeup water. The condensate transfer system at some plants is potentially contaminated with relatively low levels of radioactivity. If the condensate transfer system is used during ICS operation, the possibility exists to steam away the contaminated water to areas outside the reactor building. If raw water from the fire system is used during ICS operation, the potential exists to contaminate the isolation condenser internals with chlorides, thereby increasing the prospects for intergranular stress corrosion cracking of isolation condenser stainless steel components.

Even though these drawbacks exist, they are far outweighed by the need of the ICS to mitigate the possibility of core damage due to a loss-of-coolant accident (LOCA).

\subsubsection{Reactor Protection System}

The reactor protection system supplies reactor water level and reactor pressure input to the ICS initiation logic. A failure of the ICS to automatically initiate would require the operators to manually open the outboard condensate return valve.

\subsubsection{Reactor Recirculation System}

The ICS returns condensate to the reactor via a connection to the suction side of a selected reactor recirculation pump. The Oyster Creek and Nine Mile Point 1 plants each have five recirculation pumps. Each ICS loop returns condensate to a separate pump. The Millstone Unit 1 and Dresden 2 and 3 plants have two recirculation pumps, and the ICS returns condensate to one recirculation pump. The reactor recirculation system is procedurally controlled to maintain an open pathway for the ICS to return condensate to the reactor.

\subsubsection{Main Steam System}

During standby operations, the ICS vents noncondensible gases downstream of the main steam isolation valves via the ICS vent valves to the main steam system. If the main steam system has failed during reactor operation, the ICS would most likely be in service and the ICS vent valves would be closed. 


\subsubsection{Instrument/Service Air Systems}

The plant instrument/service air system supplies air to the operators of the ICS vent valves. A loss of the air system will cause the vent valves to close.

\subsubsection{Electrical Systems}

The $480 \mathrm{VAC}$ is used to power the inboard steam supply and condensate return valve operators, and $125 \mathrm{VDC}$ is used to operate the outboard steam supply and condensate return valve operators. DC power is also used to power the air pilot solenoids for the ICS vent valves. The loss of electrical power to the steam supply and condensate return valves will cause the valves to fail in the "as-is" position. The loss of power to the air pilot solenoids will cause the vent valves to fail to the closed position. 


\subsection{Safety Significance}

The following sections describe the safety significance of ICS in mitigating design basis accidents. Also described is the regulatory guidance that helps determine the importance of the ICS with respect to other reactor systems and components.

\subsection{Design Bases}

The ICS is required to function during a small break LOCA to assist the automatic depressurization system (ADS) in depressurizing the reactor as a backup to the plant high pressure injection systems. Using the ICS during a LOCA condition serves two functions: 1) it minimizes the loss of reactor water inventory to the torus, which normally occurs during ADS blow down, and 2) it allows earlier initiation of low pressure injection systems.

\subsection{Individual Plant Evaluation}

The ICS plays a key role in mitigating core damage during a severe accident. Assuming that each of the five plants has the same general design, the ICS should have the same relative importance from plant to plant. To explain the importance of the ICS, the Millstone Unit 1 IPE was used as an example. The IPE states that the isolation condenser, which can operate independently of AC power, is a key system that can prevent core damage for several hours in a station blackout sequence, which increases the likelihood of recovering $A C$ power prior to core damage (Northeast Utilities Service Company 1992, p. 7-1). One-third of the core melt frequency is due to sequences including a loss of normal power as an initiating event, the failure of the diesel and gas turbine generators, the failure to manually initiate the isolation condenser prior to safety relief valves (SRVs) lifting, and an SRV sticking open. In this scenario, no credit is taken for recovery of $\mathrm{AC}$ power because of the assumed short time to core uncovery. The lack of an AC-independent high pressure injection system, such as high pressure coolant injection (HPCI) or reactor core isolation cooling (RCIC), contributes to the vulnerability of Millstone Unit 1 to this scenario (Northeast Utilities Service Company 1992, p. 7-2).

\subsection{Regulatory Guidance}

The NRC has developed regulatory guides that designate the relative importance of systems and components to ensure their adequacy, availability, and capability to perform their intended functions. Guides relevant to the ICS include the following:

- NRC Regulatory Guide 1.29, Seismic Design Classification, classifies the ICS as Seismic Category I.

- NRC Regulatory Guide 1.26, Quality Group Classifications and Standards for Water-, Steam-, and Radioactive-Waste-Containing Components of Nuclear Power Plants, classifies 
the valves and piping in the ICS from the reactor pressure vessel to the outer most containment valve as Quality Group A.

The ICS falls within the scope of the monitoring program defined by the Maintenance Rule 10 CFR 50.65 because it meets the definition of a safety-related system. The ICS is defined as a safetyrelated system because it is relied upon to remain functional during and following design basis events to ensure 1) the integrity of the reactor coolant pressure boundary, 2) the capability to shut down the reactor and maintain it in a safe shutdown condition, and 3) the capability to prevent or mitigate the consequences of accidents that could result in potential offsite exposure. 


\subsection{Methodology}

The operating history of the ICS was explored to identify the aging-related issues associated with the system. The search was conducted by accessing the available industry databases, which consisted of the nuclear plant reliability database system (NPRDS), nuclear power experience (NPE), RECALL $^{(a)}$ database, and literature searches at the Hanford Technical Library. These searches yielded maintenance records, license event reports (LERs), and NRC information notices. NPRDS was the primary source of aging degradation information for individual components and is the primary focus in this report. The RECALL database, NPE, and the literature searches performed at the Hanford Technical Library were valuable sources for the descriptions of plant events (LERs and NRC information notices) that involved ICS malfunctions. Most of the malfunctions could be traced back to the component failures in NPRDS.

(a) Commercially available to PNL. 


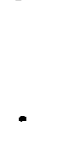




\subsection{Results and Evaluation}

The NPRDS search was performed by staff at the Oak Ridge National Laboratory (ORNL). The search was on the key words: "isolation condenser." Approximately 250 maintenance records were found on file. The records were divided into separate components and, for the purposes of this report, were further subdivided into three general categories: electrical, instrumentation, and mechanical. These records describe the component that failed and the cause of the failure. From this information, it could be ascertained whether or not the failure was aging-related. Also, as part of the research methodology, each ICS component was evaluated to determine if it had been included as part of a previous aging assessment under the NPAR program. The following summarizes the findings from the NPRDS search.

\subsection{Electrical}

The electrical category divides into two sub-categories, circuit breakers and relays for a total of 15 records. NPRDS shows nine failures of breakers for ICS valve operators and six records of failures of time-delay relays. Although there is evidence of aging in these components, circuit breakers and relays have been studied in a separate NPAR task (Gleason 1992).

\subsection{Instrumentation}

There were 134 records found that referred to failures of ICS instrumentation. Of these, 113 records referred to instrumentation of primary concern that includes inputs into initiation and isolation logics. These instruments included differential pressure switches and pressure transmitters. The remaining records listed failures of instruments used to monitor temperature, radiation, and condenser shell level.

About 100 records indicated set-point drift and instrument repeatability as the failure mode. In a number of cases, repeatability of the instrument was either not adequate for system design or the operating band was larger than the technical specification tolerance. In these cases, the system was upgraded to meet the technical specifications requirements.

Set-point drift is discussed in NUREG/CR-5700, Aging Assessment of Reactor Instrumentation and Protection System Components (Gehl and Hagan 1992, pp. 58-59):

Instrumentation and control systems in nuclear plants are typically provided with adjustable set points where specific actions are initiated. Each of these adjustable set points is assigned a preset value. Set-point drift is the unplanned change in these preset values. When the change is of sufficient magnitude to cause the set point to fall outside specified limits, the event may be classified as an abnormal occurrence that must be reported to NRC. 
A 1977 report (Basin et al. 1977) credited set-point drift problems as being "influenced by the initial selection of the instruments, their range, application, calibration, operation, and maintenance procedures." Aging was not considered as a factor in either that report or a 1974 report (Hartfield 1974).

The term "drift" is often used erroneously as a synonym for the term "aging related." Set-point drift is sometimes erroneously considered an indication of an aging-related problem.. Although modules with aging-related problems may be more likely to have excessive drift problems, set-point drift does not reliably indicate that an aging-related problem exists. Set-point drift is affected by the module's design, application, calibration, and maintenance and operation procedures as well as aging-related problems.

In light of the aging research on reactor instrumentation documented in NUREG/CR-5700 (Gehl and Hagen 1992) and the fact the ICS instrumentation does not operate in any unique environments, further study of ICS instrumentation is not required.

\subsection{Mechanical}

The mechanical general category includes pipe, supports, and valves. A total of 102 records address failures in these areas and ten of these records reported failure in ICS piping. All the failures were related to intergranular stress corrosion cracking in weld heat affected zones. Most of the cracks were found during in-service inspections. Aging research has been performed for BWR piping (Shah and MacDonald 1993). Because the ICS is exposed to the same environment (e.g., reactor coolant chemistry) as discussed in Shah and MacDonald, further research on ICS piping is not required.

Thirty-one records describe failure of the ICS pipe snubbers. Of these, 13 records indicated that the snubbers were incorrectly installed and 18 records noted some type of aging concern. Most of the records that noted aging stated that the snubbers were easily replaced, and the operation of the ICS was not affected. PNL completed Phase II aging research of snubbers in 1991 (Brown et al. 1992). Snubbers are not within the scope of this report.

Sixty-one records discuss failures of ICS valves and valve operators. The most frequent valve failures were due to packing leaks. Packing leaks do not necessarily affect the operation of the critical ICS valves that are required for system initiation and isolation. These valves are motor operated. ICS valves fall within the scope of an aging study on motor-operator valves, NUREG/CR-4234 (Haynes 1989). Thermal binding was also a cause of valve degradation and accelerated aging. Procedures are in place in the affected plants to cycle the valves during plant cool down to mitigate this problem.

\subsection{Isolation Condensers}

The isolation condenser does not appear to fall within the scope of any other NPAR research. Moyers (1992) does address the aging of heat exchangers, but only water-to-water heat exchangers. 
The isolation condenser's primary and secondary media go through a phase change during ICS operation. This type of heat exchanger is not addressed in Moyers (1992).

Prior to the investigation of isolation condenser aging, it was expected that problems might be found with the tubes in the isolation condensers. This expectation was based on the tube failure problems found in PWR steam generators. However, only one plant had recorded problems with isolation condenser tube failure.

In February 1976, Millstone Unit 1 experienced a reactor scram from $100 \%$ power because of a turbine generator trip. The subsequent pressure spike, caused by the turbine control valves closing, ruptured a tube in the isolation condenser. A follow-up investigation revealed that the stainless steel tube showed evidence of cracking characteristic of chloride-assisted, stress corrosion cracking that initiated from the inside of the tube. The corrosive species is believed to have been introduced into the condenser tubes several years prior to the event when the plant had an incident involving the injection of seawater into the isolation condenser. The plant operators re-tubed the condenser with Inconel 600 tubes (NPE 1976 and General Electric 1976).

As a result of this incident, the NRC issued Inspection and Enforcement Bulletin 76-01 (Appendix A). Among other things, the NRC required that licensees ensure that the integrity of the isolation condenser tubes was being maintained during plant operation. Tube integrity is confirmed by implementing tube leak detection procedures that call for monitoring the shell-side water temperature, volume, and isotopic content. If any of these parameters increases, a tube leak is suspected. The NRC also required that the licensees ensure that the margin of isolation condenser tube integrity is maintained by periodic nondestructive examinations of the tubes. Where nondestructive examination can not be performed, hydrostatic testing is an acceptable alternative. From the available information, four plants directly referenced procedures to hydrostatically test and/or to test the heat removal capability of the isolation condenser on a 5-year cycle.

The paucity of isolation condenser tube failures as compared with the significant problems that PWR reactor steam generators have experienced with tube degradation and failure can be understood in terms of key differences in thermal and flow conditions, secondary side chemistry, and materials.

Steam generators are in constant operation when the reactor is at power. The secondary side of the tube bundle is subjected to a phase change of the secondary coolant from liquid to steam, which requires a flow through the tube bundle and its tube supports. Corrosion of the tube support members restricts secondary flow through the tube bundle and will ultimately "dent" the tube and also restrict the flow of primary coolant through the tube. Many of the tube failures occur where the tube intersects the tube supports, at the high stress areas of the tube U-bends, and at the tube sheet. Steam generator tubes are periodically subjected to nondestructive testing and inspection. Tubes that show indication of imminent failure are plugged or replaced.

The isolation condensers, in contrast to the PWR steam generators, are in a standby condition and will be for most of their operating life. The tube bundles are constantly submerged in demineralized 
water $\left[<93^{\circ} \mathrm{C}\left(<200^{\circ} \mathrm{F}\right)\right]$. In addition, the shell side of the isolation condenser is continuously vented to atmosphere. The primary side of the tube bundles is exposed to reactor coolant that is "dead legged" against the condensate return valve. The steam supply to the isolation condenser vents noncondensibles upstream of the tube bundles.

The isolation condenser, therefore, is not exposed to the same dynamics as a steam generator. This lack of exposure is apparently the reason that the isolation condensers have not evidenced the same degree of aging degradation. 


\subsection{Simplified BWR Isolation Condenser System}

The SBWR is a nominal 600-MWe reactor that is being designed by General Electric. The SBWR incorporates simplified systems and passive emergency equipment into its design. As part of the design of the emergency equipment, the designers have brought back the ICS. The SBWR ICS operates on much the same philosophy as the present day isolation condensers, but the system configuration is somewhat different. The ICS for the SBWR consists of three independent loops, each containing an isolation condenser that condenses steam on the tube side and transfers the heat to a large pool that is vented to the atmosphere. The isolation condensers, connected by piping to the reactor pressure vessel, are placed at an elevation above the reactor and, when the steam is condensed, the steam condensate returns to the vessel via a condensate return pipe. Each isolation condenser is designed for a 30-MWt capacity. The SBWR ICS operates with the same type of initiating and isolation logic as conventional plants. In addition, the SBWR isolation condensers will also isolate on high radiation levels. 


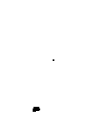




\subsection{Conclusions and Recommendations}

A preliminary aging assessment of the ICS was conducted in terms of the major system interfaces and system components. System interface failures are adequately addressed based on the inherent design characteristics of the ICS. For example, there are redundant sources of condenser shell makeup water. Similarly, if there is a loss of electrical power, valves can be manually operated for system initiation or isolation.

After researching the available databases for aging of the ICS, it was determined that most of the system components experience aging degradation in some form. However, all of the ICS components, except the isolation condenser, have been or are being studied by other NPAR tasks. Only the isolation condenser requires further aging consideration. The operating history of the isolation condenser component has been good. The only mark on that history has been the Millstone incident, and the initiating cause of the Millstone incident was an event that allowed chloride intrusion into the condenser during construction. This situation resulted in stress corrosion cracking of the tube bundle and ultimate failure of a tube during a pressure transient a number of years after installation and reactor startup.

An effort also was made to compare the isolation condenser with the PWR steam generator because the steam generators have experienced many problems with tube degradation and failure. The obvious difference between the two components is that the steam generator operates in a much more dynamic environment than the isolation condenser. The isolation condenser operates in a standby and static condition and is rarely called into service. The isolation condensers have greater longevity because they are not exposed to the same dynamics and environment as the steam generators.

Finally, a concern exists for undetected aging degradation of the isolation condensers because of their relatively long service record. The isolation condenser is only one tube break away from releasing primary coolant to the environment. The NRC requires the licensees, in Inspection and Enforcement Bulletin 76-01 (Appendix A), to verify that tube leaks are not present in the isolation condensers and to ensure that the tube integrity margin is maintained. Nondestructive examination is the preferred approach, but hydrostatic testing is an acceptable alternative.

Additional evaluation of isolation condenser aging is recommended to determine if the tubes are potentially subject to long-term degradation that may require the more sensitive non-destructive examination methods to ensure that tube integrity will continue to be maintained. Additional consideration of this concern may also provide beneficial input into the design of the SBWR. 
. 


\subsection{References}

Basin, S. L., E. T. Burns, V. Cini, and W. S. Loell. 1977. Characteristics of Instrumentation and Control System Failures in Light Water Reactors. EPRI NP-443, prepared by Science Applications, Inc., for the Electric Power Research Institute, Palo Alto, California.

Brown, D. P., E. V. Werry, and D. E. Blahnik. 1992. Results of LWR Snubber Aging Research. NUREG/CR-5870, PNL-8051, prepared by Pacific Northwest Laboratory for the U.S. Nuclear Regulatory Commission, Washington, D.C.

Gehl, A. C., and E. W. Hagen. 1992. Aging Assessment of Reactor Instrumentation and Protection System Components. NUREG/CR-5700, ORNL/TM-11806, prepared by Oak Ridge National Laboratory for the U.S. Nuclear Regulatory Commission, Washington, D.C.

General Electric. 1976. Isolation Condenser Tubing Inspection, No. 185. Dated July 30, 1976. General Electric BWR Services Information Letter, General Electric Nuclear Energy Projects Division, San Jose, California.

Gleason, J. F. 1992. Comprehensive Aging Assessment of Circuit Breakers and Relays for Nuclear Plant Aging Research (NPAR), Phase II. NUREG/CR-5762, WYLE 60101, prepared by Wyle Laboratories for the U.S. Nuclear Regulatory Commission, Washington, D.C.

Hartfield, R. A. 1974. Setpoint Drift in Nuclear Power Plant Safety-Related Instrumentation. OOEES-003, Office of Operations Evaluation, U.S. Atomic Energy Commission, Washington, D.C.

Haynes, H. D. 1989. Aging and Service Wear of Electric Motor-Operated Valves Used in Engineered Safety-Feature Systems of Nuclear Power Plants. NUREG/CR-4234, Vol. 2, ORNL-6170/V2, prepared by Oak Ridge National Laboratory for U.S. Nuclear Regulatory Commission, Washington, D.C.

Moyers, J. C. 1992. Aging of Non-Powers-Cycle Heat Exchangers Used in Nuclear Power Plants. Vol. 1. ORNL-6687/V1, Oak Ridge National Laboratory, Oak Ridge, Tennessee.

Northeast Utilities Service Company. 1992. Millstone Unit No. 1 Individual Plant Examination for Severe Accident Vulnerabilities. NUSCO 174, prepared by Northeast Utilities Services Company for the Northeast Nuclear Energy Company, Berlin, Connecticut. 
Nuclear Power Experience (NPE), Vol. BWR-2, VII Safety Systems, F, No. 28, Dated December 1976.

Shah, V. N., and P. E. MacDonald, eds. 1993. Aging and Life Extension of Major Light Water Reactor Components. Elsevier, New York. 


\title{
APPENDIX A
}

\section{Bulletin 76-001 - BWR ISOLATION CONDENSER TUBE FAILURE}

\author{
NUCLEAR REGULATORY COMMISSION \\ OFFICE OF INSPECTION AND ENFORCEMENT \\ WASHINGTON, D. C. 20555 \\ Inspection and Enforcement Bul letin (IEB) \\ Number 76-01. March 9. 1976
}

\section{BWR ISOLATION CONDENSER TUBE FAILURE}

\section{DESCRIPTION OF CIRCUMSTANCES:}

On February 12, 1976. an electrical fault in the main transformer at the Millstone Unit 1 facility caused an automatic shutdown of the reactor plant from full power. Shortly after the shutdown, a small amount of radioactive steam and water was discharged from the isolation condenser vent as a result of tube failure in the isolation condenser. This discharge of radioactive water and steam caused low levels of contamination on the ground immediately outside of the reactor building. This contamination was removed and no resulting contamination was found outside the plant area.

Subsequent visual inspection of the isolation condenser tubes revealed that one tube had a one inch hole in the tube wa17 at the " $U$ " bend. Metallographic examination showed cracking of the tube in both the bend and in the straight section adjacent to the bend. Eddy current testing of the remaining tubes indicated that approximately 30 percent of the tubes have extensive cracking to a depth greater than that a110wed for minimum wa 11 thickness. In addition, other indications of possible tube defects have been found in the region of the tube sheet. These possible tube defects are currently under evaluation.

\section{ACTIONS REQUIRED BY LICENSEES:}

A11 licensees of BWR power reactor facilities with isolation condensers or an equivalent installation are to take the following actions:

1. Provide a description of the steps taken or planned to:

a. Assure that the integrity of the isolation condenser tubes is being maintained during operations. This assurance may be obtained by the implementation of tube leak detection procedures such as procedural controls for the temperature, volume and isotopic content of the she11 side water.

b. Assure that the margin of isolation condenser tube integrity is maintained. This assurance may be obtained by periodic nondestructive 
examinations of the tubes. In the event nondestructive examinations of the tubes cannot be

performed, hydrostatic testing, in accordance with the 1974 ASME Section XI requirements, is an acceptable alternate. The next nondestructive or

hydrostatic testing should be performed at the first practicable opportunity. but no later than the next refueling outage.

c. Assure prompt detection and operator response to an isolation condenser tube break.

2. A report of the above descriptions and plans should be submitted within 20 days after receipt of this bulletin.

3. A report of the performance, the results, and the evaluation of the next nondestructive examination of the tubes should be submitted within 30 days following completion of the examination.

Reports should be submitted to the Director of the NRC Regional Office, and a copy should be forwarded to the NRC Office of Inspection and Enforcement. Division of Reactor Inspection Programs, Washington. D. C. 20555.

Approval of NRC requirements for reports concerning possible generic problems has been obtained under 44 U.S.C. 3512 from the U. S. General Accounting office.

(GOA Approval B-180255(R0072), expires 7/31/77.) 


\section{Distribution}

No. of

Copies

\section{OFFSITE}

21 U.S. Nuclear Regulatory Commission Washington, D.C. 20555

ATTN: S. K. Shaukat (20)

$$
\text { J. P. Vora }
$$

R. L. Lofaro

Brookhaven National Laboratory

Upton, NY 11973

B. Poole

Oak Ridge National Laboratory

P.O. Box 2009

Oak Ridge, TN 37831

L. Magelby

Idaho National Engineering Laboratory

P.O. Box 1675

Idaho Falls, ID 83415
No. of

Copies

S. P. Nowlen

Sandia National Laboratory

P.O. Box 5800

Albuquerque, NM 87185

\section{ONSITE}

DOE Richland Operations Office

D. C. Langstaff $\quad \mathrm{K} 8-50$

21 Pacific Northwest Laboratory

M. E. Cunningham

$\mathrm{K} 8-43$

A. B. Johnson

K8-34

J. V. Livingston

K8-37

R. D. Orton (10)

K8-33

N. J. Stratton

K8-14 
. 